\title{
Tailor-Made Therapy for Viral Hepatitis: Recent Advances
}

\author{
Masatoshi Kudo \\ Department of Gastroenterology and Hepatology, Kinki University School of Medicine, Osaka-Sayama, Japan
}

\section{Key Words}

Hepatitis C · Hepatitis B • Interleukin-28B - Inosine triphosphatase $\cdot$ Pegylated interferon ribavirin therapy . Double-filtration plasmapheresis

\begin{abstract}
Combination therapy of pegylated interferon- $\alpha$ with ribavirin (PEG-IFN/RBV) is a standard of care for chronic hepatitis C (CHC). The majority of $\mathrm{CHC}$ patients are infected with $\mathrm{HCV}$ genotype I. The recent discovery revealed by a genome-wide association study technology provides the important role of interleukin-28B (IL28B) and inosine triphosphatase (ITPA) in HCV infection. In addition, response to PEG-IFN/RBV therapy is correlated with insulin resistance, hepatic steatosis, and hepatic fibrosis in $\mathrm{CHC}$ patients. Double-filtration plasmapheresis together with IFN therapy has proved to be effective in the reduction of viral load during the early stage of treatment. In CHC patients, not only IL28B status, but also the treatment period of PEG-IFN/RBV is important. Even when new polymerase/protease inhibitors are introduced in the treatment of $\mathrm{CHC}$, tailor-made treatment for $\mathrm{CHC}$ using IL28B, inosine triphosphatase testing or double-filtration plasmapheresis treatment prolonged treatment strategy is highly recommended. The relative etiologic role of prior hepatitis $B$ virus infection in the development of non- $B$ non- $C$ hepatocellular carcinoma is also known in hepatitis B-endemic areas.
\end{abstract}

Copyright $\odot 2011$ S. Karger AG, Basel

\section{KARGER}

Fax +4161306 1234

E-Mail karger@karger.ch

www.karger.com
(C) 2011 S. Karger AG, Basel

0012-2823/11/0845-0001\$38.00/0

Accessible online at:

www.karger.com/dig

\section{Introduction}

The 8th Japan-Korea Liver Symposium, the main theme of which was 'Tailor-made therapy of viral hepatitis', was held in Kobe, Japan, on July 17, 2011, to focus on and discuss current topics in viral hepatitis. The symposium was full of enlightening lectures by world's leading scientists, followed by extensive discussions. This supplement issue of Digestion contains the most important articles presented at this meeting.

\section{Insulin Resistance}

Insulin resistance (IR) has been reported to be an independent predictor of treatment outcome in chronic hepatitis $\mathrm{C}(\mathrm{CHC})$ patients.

Associations among IR, steatosis and liver fibrosis have been observed in $\mathrm{CHC}$ patients [1-5]. IR has been suggested as the cause, more than a consequence, of hepatic steatosis and fibrosis in patients with $\mathrm{HCV}$, particularly in those with genotype 1 infection [6]. The mechanisms of the more obvious and crucial influence of IR, more than steatosis and fibrosis, need further study. IR seems to be at least associated with body mass index and steatosis, but not with hepatic fibrosis [7]. 


\section{Double-Filtration Plasmapheresis}

The use of double-filtration plasmapheresis (DFPP), approved in Japan in April 2008 for the retreatment of chronic $\mathrm{CHC}$ patients with genotype $1 \mathrm{~b}$ and high viral loads, together with IFN administration has produced a substantial reduction in the viral load during the early stages of treatment and has effected a high sustained virological response (SVR) $[8,9]$, suggesting that this treatment is a new modality for difficult-to-treat $\mathrm{CHC}$ patients.

Recent reports have revealed factors associated with response to pegylated interferon- $\alpha$ with ribavirin (PEGIFN/RBV) therapy such as single nucleotide polymorphisms (SNPs), as host genetic factors, located in interleukin-28B (IL28B; rs8105790, rs11881222, rs8103142, rs28416813, rs4803219, rs8099917, rs7248668, and rs12979860) on chromosome 19 [10-13]; amino acid (aa) substitutions in nonstructural protein $5 \mathrm{a}$, especially those in the IFN/RBV resistance-determining region [14] and the IFN sensitivity-determining region (ISDR) [15], and the core regions of HCV [16], as viral genetic polymorphisms.

Kim et al. [17] reported that early viral dynamics with DFPP + IFN- $\beta /$ RBV then PEG-IFN/RBV therapy is superior to the previous PEG-IFN/RBV combination therapy. There was a significant difference in viral reduction at 24 and $48 \mathrm{~h}$, and 1, 2, 4, 8 and 12 weeks between nonviral response (NVR) and relapse patients. The rate of rapid viral response (RVR) and complete early viral response (cEVR) showed a significant difference between NVR and relapse patients: among the 20 patients, RVR was obtained in $75 \%(6 / 8)$ of relapse patients but in $0 \%$ $(0 / 12)$ of NVR patients, and cEVR in $88 \%$ (7/8) of relapse patients but in only $8 \%(1 / 12)$ of NVR patients. On the basis of the above results, DFPP + IFN- $\beta /$ RBV then PEGIFN/RBV therapy is indicated more for relapse than for NVR patients. We could conclude that relapse patients would be better candidates than NVR patients [17].

\section{IL28B and Inosine Triphosphatase}

The recent discovery revealed by a genome-wide association study (GWAS) technology provides the unexpected role of IL28B and inosine triphosphatase (ITPA) in $\mathrm{HCV}$ infection. The former SNPs around the IL28B gene could improve the diagnostics on the prediction of spontaneous clearance and the response to anti-HCV treatment, suggesting that these findings could be strong evidence to enhance the development of a novel therapeutic strategy and the basic study of IFN- $\lambda$ s. Interestingly, the discovered IL28B SNPs revealed the enigma that the viral clearance rate was dependent on ethnic type. The latter functional SNP in ITPA locus was the most significant SNP associated with RBV-induced anemia as well as IFNinduced thrombocytopenia. Note that severe $\mathrm{Hb}$ decline, which is mainly found in ITPA-CC patients, was inversely correlated with platelet reduction, contributing to an association between severe anemia and relative reactive increase in platelet count.

The efficacy of triple therapy of telaprevir/PEG-IFN/ RBV was high in the patients with genotype TT (rs8099917), who achieved SVR (84\%), irrespective of substitution of core aa70. In the patients having genotype non-TT, those of Arg70 gained high SVR rate (50\%), and SVR rate $(12 \%)$ was the worst in patients who possessed both genotype non-TT and Gln70 (His70), suggesting genetic variation near the $I L 28 B$ gene and aa substitution of the core region as predictors of SVR to a triple therapy in Japanese patients infected with HCV genotype $1 \mathrm{~b}$ [18].

Genetic variants leading to ITPA deficiency, a condition not thought to be clinically important, protect against hemolytic anemia in $\mathrm{CHC}$ patients receiving $\mathrm{RBV}$ [19]. Results obtained in one GWAS study need to be evaluated in the context of different geographical and racial populations and independent cohorts. Tanaka confirmed that ITPA SNP (rs1127354) was a useful predictor of RBVinduced anemia in Japanese patients [20]. Excluding those with genotype $1 \mathrm{~b}$ and high viral load, patients with ITPA minor variant A achieved significantly higher SVR rates than those with the major variant (CC; 96 vs. $70 \%$, respectively, $p=0.0066$ ) [20]. Because the typical PEGIFN/RBV treatment period is shorter (24 weeks) in genotype 1 low viral load and genotype 2 patients than in genotype 1 high viral load (48 weeks) patients, early dose reduction in RBV may be more critical for the final outcome.

The recent discovery revealed by GWAS technology provides the unexpected role of IL28B and ITPA in HCV infection. These data may provide a valuable pharmacogenetic diagnostic tool for tailoring PEG-IFN/RBV dosing to minimize drug-induced adverse events and for further optimization of clinical anti-HCV chemotherapeutics.

\section{Total PEG-IFN Dose, Core 70 Substitution and ISDR Substitution}

Takita et al. [21] showed in their multivariate analysis that rs8099917 genotype and total PEG-IFN dose contribute to the successful outcome of PEG-IFN plus riba- 
virin combination treatment for infection with HCV genotype 1 . The study indicated the value of a combination of the rs8099917 genotype and core 70 substitutions for prediction of SVR. The patients with the rs 8099917 genotype TT had high rates of SVR (67.9\%). SVR was achieved by $30.7 \%$ of patients with the rs 8099917 genotype non-TT and core 70 wild type. The SVR rate was worst in patients with rs8099917 genotype non-TT and core 70 mutant type. These results indicate the effects of both host and viral factors on IFN responsiveness. However, a combination of the IL28 genotype and ISDR substitutions for prediction of SVR was not useful.

\section{Etiologic Role of Prior Hepatitis B Infection and Nonalcoholic Steatohepatitis on Hepatocellular Carcinoma Occurrence}

A previous study on 1,145 Korean patients showed that the prevalence of cryptogenic hepatocellular carcinoma (HCC) was significantly increased during the last decade, and patients with cryptogenic HCC had a tendency to have risk factors for nonalcoholic fatty liver disease (NAFLD) such as DM, hypertension and obesity than those with virus or alcohol-related HCC [22]. It can be assumed that the increased proportion of risk factors for NAFLD may contribute to the development of cryptogenic HCC. However, there has been no study to compare the relative etiological role of prior HBV infection and NAFLD in the development of NBNC-HCC in HBV-endemic areas. Cho et al. [23] show in their study that the relative proportion of NAFLD-related HCC increased more than three times during the past 10 years, while that of prior HBV infection-related HCC decreased. A growing trend towards a rise in NAFLD-related HCC is expected in the near future, while the prevalence of new HBV infection has definitely decreased due to universal vaccination programs but that of NAFLD has increased recently [24].

\section{Predictions of HBsAg Seroclearance}

In chronic $\mathrm{HBV}$ infections, $\mathrm{HBs} \mathrm{Ag}$ seroclearance reportedly occurs at a rate of $0.50-2.26 \%$. Several factors have been suggested to be associated with seroclearance including age and $\mathrm{HBeAg}$ negativity. However, there are few studies evaluating whether HBV DNA levels are an independent predictor of HBsAg seroclearance.

Old age, a sustained inactive phase, and low levels of $\mathrm{HBV}$ DNA were the independent predictors of $\mathrm{HBsAg}$ seroclearance [25]. The authors showed that HBsAg seroclearance occurred at a rate of $1.8 \%$ per year in $\mathrm{HBeAg}$ negative chronic hepatitis $\mathrm{B}$ patients. In addition, multivariable analysis suggested that low HBV DNA levels, old age, and sustained inactive phase were independent predictors of HBsAg seroclearance, but use of antiviral agents was not. Therefore, spontaneous HBsAg seroclearance takes place in elderly patients with low serum HBV DNA levels $(<2,000 \mathrm{IU} / \mathrm{ml})$ who remain in a sustained inactive phase.

\section{Non-B Non-C HCC}

NBNC-HCC is associated with several etiologic factors such as alcoholic liver diseases (ALD) autoimmune hepatitis, primary biliary cirrhosis, primary sclerosing cholangitis, and NAFLD/nonalcoholic steatohepatitis. In addition, a variety of clinical factors are also involved in the development and progression of NBNC-HCC, including age, sex, alcohol consumption, and diabetes mellitus $[26,27]$. There are only a few reports, however, on the clinical characteristics of NBNC-HCC, and the actual state of NBNC-HCC has not been fully elucidated [28-31].

Although the number of patients with NBNC-HCC has been increasing annually, many features of NBNCHCC remain unknown. Based on the present study, the most common etiologic factor for NBNC-HCC was alcohol, and diabetes may be related to the occurrence of HCC in patients with non-alcohol-related liver disease. The comparison between groups revealed that nonALD-HCC tended to be detected at a more advanced stage, whereas liver function in ALD-HCC was worse. Finally, the prognosis was equivalent between groups [32].

\section{Conclusion}

Tailor-made treatment for chronic hepatitis is a very important issue to be addressed even when new polymerase/protease inhibitors are available.

\section{Disclosure Statement}

The author has no conflict of interest to declare. 


\section{References}

- 1 Hsieh MH, Lee LP, Hsieh MY, Tsai KB, Huang JF, Hou NJ, Chen SC, Lin ZY, Wang LY, Dai CY, et al: Hepatic steatosis and fibrosis in chronic hepatitis C in Taiwan. Jpn J Infect Dis 2007;60:377-381.

-2 D'Souza R, Sabin CA, Foster GR: Insulin resistance plays a significant role in liver fibrosis in chronic hepatitis $\mathrm{C}$ and in the response to antiviral therapy. Am J Gastroenterol 2005;100:1509-1515.

- 3 Muzzi A, Leandro G, Rubbia-Brandt L, James R, Keiser O, Malinverni R, Dufour JF, Helbling B, Hadengue A, Gonvers JJ, et al: Insulin resistance is associated with liver fibrosis in non-diabetic chronic hepatitis $\mathrm{C}$ patients. J Hepatol 2005;42:41-46.

-4 Sud A, Hui JM, Farrell GC, Bandara P, Kench JG, Fung C, Lin R, Samarasinghe D, Liddle C, McCaughan GW, et al: Improved prediction of fibrosis in chronic hepatitis $\mathrm{C}$ using measures of insulin resistance in a probability index. Hepatology 2004;39:1239-1247.

5 Zekry A, McHutchison JG, Diehl AM: Insulin resistance and steatosis in hepatitis $\mathrm{C}$ virus infection. Gut 2005;54:903-906.

-6 Fartoux L, Poujol-Robert A, Guechot J, Wendum D, Poupon R, Serfaty L: Insulin resistance is a cause of steatosis and fibrosis progression in chronic hepatitis C. Gut 2005;54 1003-1008.

7 Kim SR, Saito J, Imoto S, Komaki T, Nagata Y, Nakajima T, Ando K, Fukuda K: Correlation between insulin resistance and outcome of pegylated interferon and ribavirin therapy, hepatic steatosis, hepatic fibrosis in chronic hepatitis C-1b and high viral load. Digestion, this issue.

-8 Fujiwara K, Kaneko S, Kakumu S, Sata M, Hige S, Tomita E, Mochida S: Double filtration plasmapheresis and interferon combination therapy for chronic hepatitis $\mathrm{C}$ patients with genotype 1 and high viral load. Hepatol Res 2007;37:701-710.

$\checkmark 9$ Kaneko S, Sata M, Ide T, Yamashita T, Hige S, Tomita E, Mochida S, Yamashita Y, Inui Y, Kim SR, et al: Efficacy and safety of double filtration plasmapheresis in combination with interferon therapy for chronic hepatitis C. Hepatol Res 2010;40:1072-1081.

-10 Tanaka Y, Nishida N, Sugiyama M, Kurosaki M, Matsuura K, Sakamoto N, Nakagawa M, Korenaga M, Hino K, Hige S, et al: Genomewide association of IL28B with response to pegylated interferon-alpha and ribavirin therapy for chronic hepatitis C. Nat Genet 2009;41:1105-1109.

11 Ge D, Fellay J, Thompson AJ, Simon JS, Shianna KV, Urban TJ, Heinzen EL, Qiu P, Bertelsen AH, Muir AJ, et al: Genetic variation in IL28B predicts hepatitis C treatment-induced viral clearance. Nature 2009;461:399401.

-12 Suppiah V, Moldovan M, Ahlenstiel G, Berg T, Weltman M, Abate ML, Bassendine M, Spengler U, Dore GJ, Powell E, et al: IL28B is associated with response to chronic hepatitis $\mathrm{C}$ interferon-alpha and ribavirin therapy. Nat Genet 2009;41:1100-1104.

13 Rauch A, Kutalik Z, Descombes P, Cai T, Di Iulio J, Mueller T, Bochud M, Battegay M, Bernasconi E, Borovicka J, et al: Genetic variation in IL28B is associated with chronic hepatitis $\mathrm{C}$ and treatment failure: a genomewide association study. Gastroenterology 2010;138:1338-1345, 1345, el331-e1337.

14 El-Shamy A, Nagano-Fujii M, Sasase N, Imoto $\mathrm{S}$, Kim SR, Hotta $\mathrm{H}$ : Sequence variation in hepatitis $\mathrm{C}$ virus nonstructural protein $5 \mathrm{~A}$ predicts clinical outcome of pegylated interferon/ribavirin combination therapy. Hepatology 2008;48:38-47.

15 Enomoto N, Sakuma I, Asahina Y, Kurosaki M, Murakami T, Yamamoto C, Ogura Y, Izumi N, Marumo F, Sato C: Mutations in the nonstructural protein $5 \mathrm{~A}$ gene and response to interferon in patients with chronic hepatitis $C$ virus $1 b$ infection. N Engl J Med 1996; 334:77-81.

16 Akuta N, Suzuki F, Kawamura Y, Yatsuji H, Sezaki H, Suzuki Y, Hosaka T, Kobayashi M, Arase Y, Ikeda K, et al: Predictive factors of early and sustained responses to peginterferon plus ribavirin combination therapy in Japanese patients infected with hepatitis C virus genotype $1 \mathrm{~b}$ : amino acid substitutions in the core region and low-density lipoprotein cholesterol levels. J Hepatol 2007;46: 403-410.

17 Kim SR, Saito J, Imoto S, Komaki T, Nagata Y, Kim KI, Sasase N, Kimura N: Double-filtration plasmapheresis plus interferon- $\beta$ for HCV-1b patients with non-sustained virogical response to previous combination therapy. Digestion, this issue.

18 Akuta N, Suzuki F, Hirakawa M, Kawamura Y, Yatsuji H, Sezaki H, Suzuki Y, Hosaka T, Kobayashi M, Saitoh S, et al: Amino acid substitution in hepatitis $\mathrm{C}$ virus core region and genetic variation near the interleukin $28 \mathrm{~B}$ gene predict viral response to telaprevir with peginterferon and ribavirin. Hepatology 2010;52:421-429.

19 Fellay J, Thompson AJ, Ge D, Gumbs CE, Urban TJ, Shianna KV, Little LD, Qiu P, Bertelsen $\mathrm{AH}$, Watson $\mathrm{M}$, et al: ITPA gene variants protect against anaemia in patients treated for chronic hepatitis C. Nature 2010; 464:405-408

20 Sakamoto N, Tanaka Y, Nakagawa M, Yatsuhashi H, Nishiguchi S, Enomoto N, Azuma S, Nishimura-Sakurai Y, Kakinuma S, Nishida N, et al: ITPA gene variant protects against anemia induced by pegylated interferon-alpha and ribavirin therapy for Japanese patients with chronic hepatitis C. Hepatol Res 2010;40:1063-1071.

21 Takita M, Hagiwara H, Arizumi T, Hayaishi S, Ueda T, Kitai S, Yada N, Inoue T, Minami Y, Chung H, et al: Association of interleukin-28B and hepatitis $\mathrm{C}$ genotype 1 with a high viral load and response to pegylated interferon plus ribavirin therapy. Digestion, this issue.

22 Oh KC, Park SH, Park JC, Jin DK, Park CS, Kim KO, Jang HJ, Lee JY, Park CH, Han TH, et al: Is the prevalence of cryptogenic hepatocellular carcinoma increasing in Korea? (in Korean). Korean J Gastroenterol 2005;45: $45-51$.

23 Cho EJ, Kwack MS, Jang ES, You SJ, Lee JH, Kim JY, Yoon JH, Lee HS: Relative etiological role of prior hepatitis $B$ virus infection and nonalcoholic fatty liver disease in the development of non-B non-C hepatocellular carcinoma in a hepatitis B-endemic area. Digestion, this issue.

24 Park NH, Chung YH, Lee HS: Impacts of vaccination on hepatitis $B$ viral infections in Korea over a 25 -year period. Intervirology 2010;53:20-28.

25 Kwak MS, Cho EJ, Jang ES, Lee JH, Yu SJ, Kim YJ, Yoon JH, Lee HS: Predictors of $\mathrm{HBsAg}$ seroclearance in HBeAg-negative chronic hepatitis B patients. Digestion, this issue.

26 Fattovich G, Stroffolini T, Zagni I, Donato F: Hepatocellular carcinoma in cirrhosis: incidence and risk factors. Gastroenterology 2004;127(suppl 1):S35-S50.

27 Hassan MM, Hwang LY, Hatten CJ, Swaim M, Li D, Abbruzzese JL, Beasley P, Patt YZ: Risk factors for hepatocellular carcinoma: synergism of alcohol with viral hepatitis and diabetes mellitus. Hepatology 2002;36 1206-1213.

28 Abe $\mathrm{H}$, Yoshizawa K, Kitahara T, Aizawa R, Matsuoka M, Aizawa Y: Etiology of non-B non- $\mathrm{C}$ hepatocellular carcinoma in the eastern district of Tokyo. J Gastroenterol 2008; 43:967-974.

29 Hatanaka K, Kudo M, Fukunaga T, Ueshima K, Chung H, Minami Y, Sakaguchi Y, Hagiwara S, Orino A, Osaki Y: Clinical characteristics of NonBNonC-HCC: comparison with HBV and HCV related HCC. Intervirology 2007;50:24-31.

-30 Kawaguchi T, Kakuma T, Yatsuhashi H, Watanabe H, Saitsu H, Nakao K, Taketomi A, Ohta S, Tabaru A, Takenaka K, et al: Data mining reveals complex interactions of risk factors and clinical feature profiling associated with the staging of non-hepatitis B virus/non-hepatitis $\mathrm{C}$ virus-related hepatocellular carcinoma. Hepatol Res 2011;41:564-571.

31 Hashimoto E, Taniai M, Kaneda H, Tokushige K, Hasegawa K, Okuda H, Shiratori K, Takasaki K: Comparison of hepatocellular carcinoma patients with alcoholic liver disease and nonalcoholic steatohepatitis. Alcohol Clin Exp Res 2004;28(suppl 2):164S-168S.

32 Kim SR, Marusawa H, Eso Y, Nishikawa $H$, Ueda Y, Kita R, Kimura T, Chiba T, Osaki Y, Kudo M: Clinical characteristics of non-B non-C hepatocellular carcinoma: a singlecenter retrospective study. Digestion, this issue. 